\title{
Phantasms of Africa: Teatro Praga's Zululuzu and Mala Voadora's Moçambique
}

\author{
FRANCESCA RAYNER
}

Título: Zululuzu. Texto e direcção: Pedro Zegre Penim, José Maria Vieira Mendes e André e. Teodósio. Interpretação: André e. Teodósio, Cláudia Jardim, Diogo Bento, Jenny Larrue, Joana Barrios, Maryne Lanaro, Gonçalo Pereira Valves, Pedro Zegre Penim. Cenografia: João Pedro Vale e Nuno Alexandre Ferreira. Figurinos: Joana Barrios. Mestre costureira: Rosário Balbi. Música original: Xinobi. Luz: Daniel Worm d'Assumpção. Som: Sérgio Henriques. Produção: Teatro Praga e Bruno Reis. Produção executiva: Sara Garrinhas. Comunicação: Teatro Praga e Clara Antunes. Local e data de estreia: São Luiz Teatro Municipal, Lisboa, 15 de Setembro de 2016.

Título: Moçambique. Texto e direcção: Jorge Andrade com Bruno Huca, Isabél Zuaa, Jani Zhao, Jorge Andrade, Matamba Joaquim, Tânia Alves, Welket Bungué. Cenografia: José Capela. Figurinos: José Capela com execução de Aldina Jesus. Vídeo: ANIMA e Bruno Canas. Banda sonora: Rui Lima e Sérgio Martins. Luz: Rui Monteiro. Coreografia: Bruno Huca. Fotografias de cena: Bruno Simão e José Carlos Duarte. Imagem de divulgação: António MV. Vídeo de divulgação: Jorge Jácome e Marta Simões. Assistência: Francisco Campos Lima. Direcção de produção: Joana Costa Santos. Apoio à produção e comunicação: Jonathan da Costa. Gestão e programação: Vânia Rodrigues. Local e data de estreia: Teatro Rivoli, Porto, 16 de Setembro de 2016.

When both Teatro Praga and mala voadora occupy Lisbon theatres at roughly the same time, it's already like having to choose between rival sound systems on the same street. When both shows have titles referencing the lusophone, the simultaneity becomes uncanny but also productive. Why have arguably the two most important theatre companies of the moment both chosen to construct performances around the Portuguese-speaking diaspora and what phantasms of this diaspora are being staged? Neither of the performances were directly about the lusophone, despite their titles. Neither were interested in examining what the different Portuguese-speaking nations might have in common. Teatro Praga explored a love-hate relationship with the hegemonic 


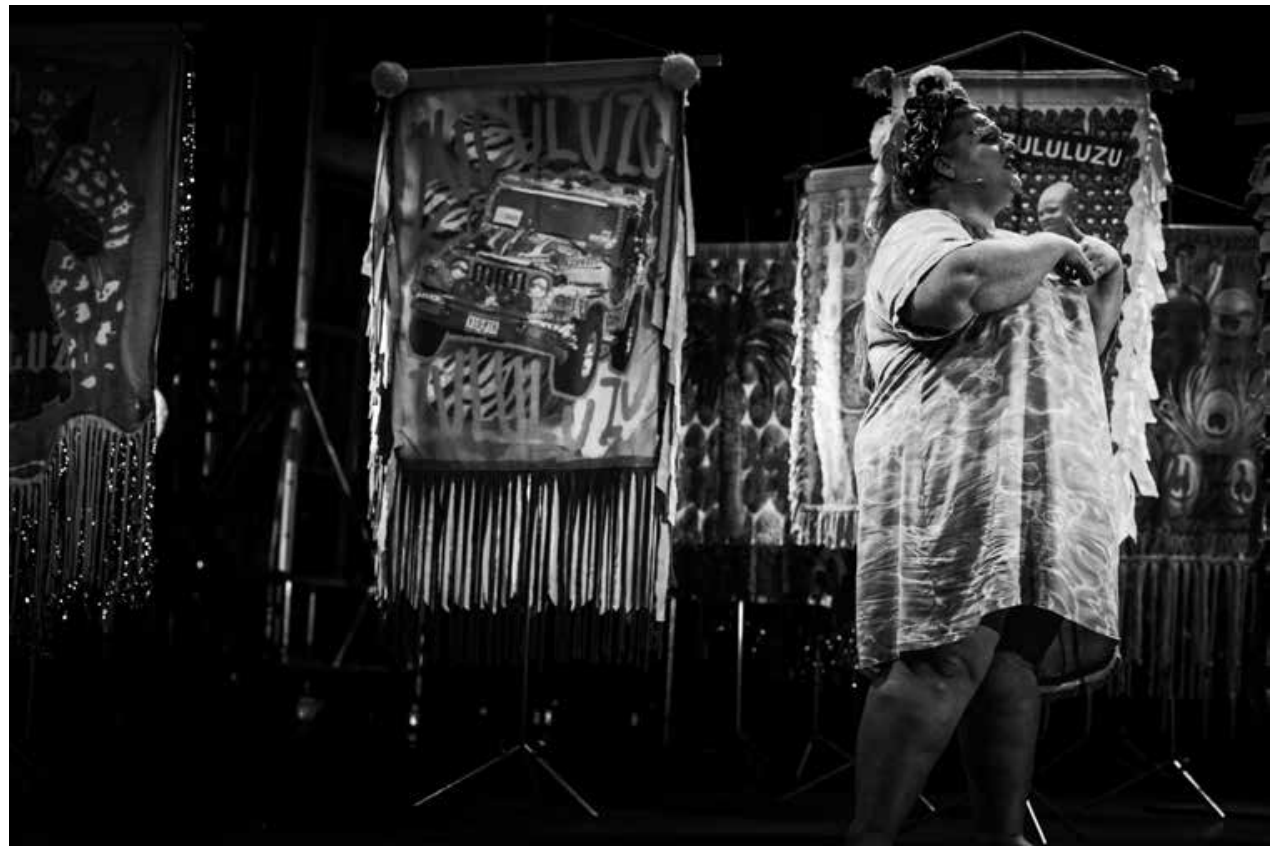

ZULULUZU, DE PEDRO ZEGRE PENIM, JOSÉ MARIA VIEIRA MENDES E ANDRÉ E. TEOdóSIO, TEATRO PRAGA, 2016 (CLÁUDIA JARDIM), 2016, [F] ESTELLE VALENTE

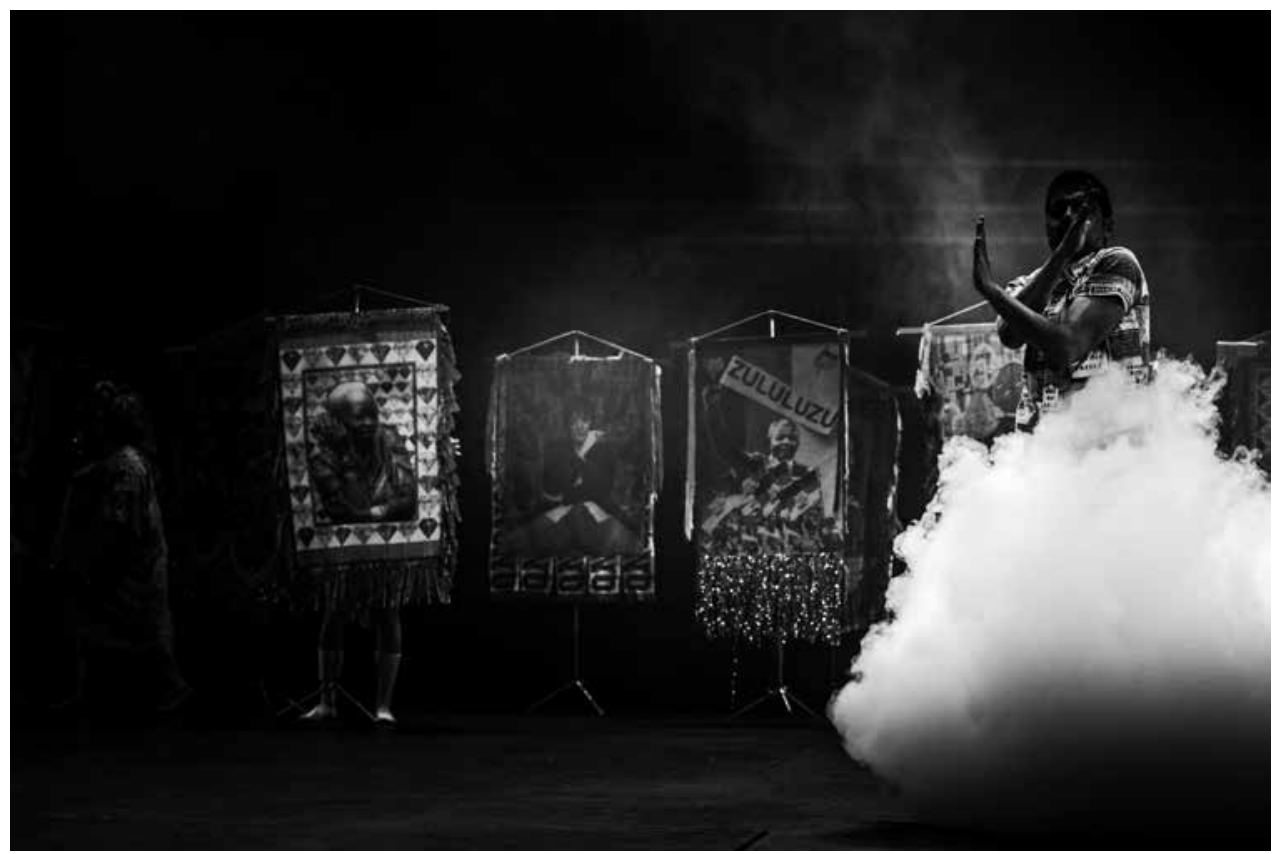

ZULULUZU, DE PEDRO ZEGRE PENIM, JOSÉ MARIA VIEIRA MENDES E ANDRÉ E. TEOdÓSIO, TEATRO PRAGA, 2016 (DIOGO BENTO), 2016, [F] ESTELLE VALENTE 


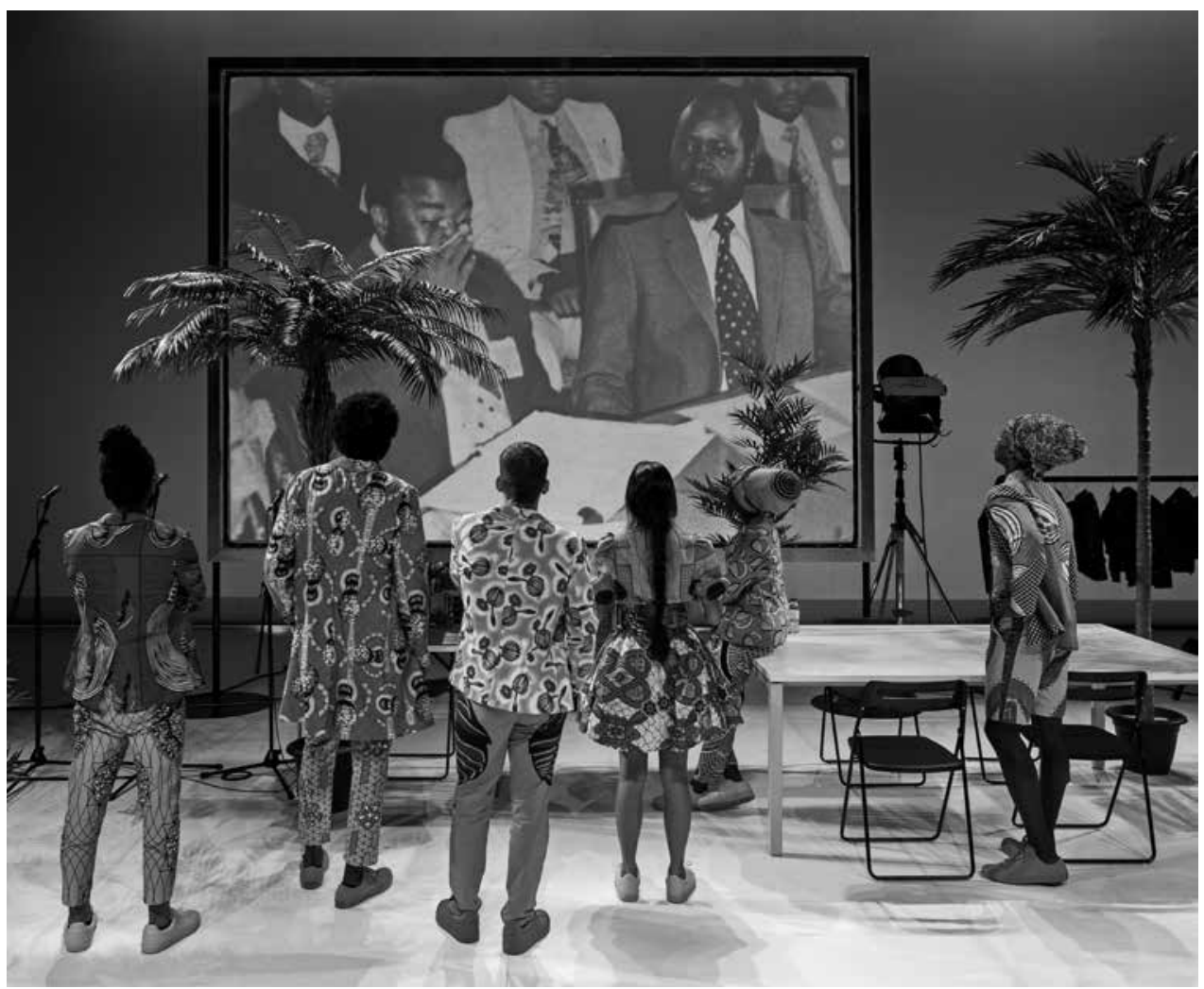

MOÇAMBIQUE, DIR. JORGE ANDRADE, MALA VOADORA, 2016 (BRUNO HUCA, MATAMBA JOAQUIM, JORGE ANDRADE, JANI ZHAO, ISABÉL ZUAA E WELKET BUNGUÉ), [F] JOSÉ CARLOS DUARTE

theatrical black box, while mala voadora deconstructed the claims of history to truth and accuracy and focused on the fallibility of documentary sources. Both, however, explored the difficulties of representing the lusophone onstage in a way that avoided cultural clichés and, in the process, commented on the exclusion of black actors and actresses from contemporary Portuguese stages.

Near the beginning of Zululuzu, the surtitles announced that no theatre would enter this performance. This coincided with an actress addressing a romantic break-up speech to the black wall at the back of the stage. Like other Teatro Praga performances, Zululuzu interrogated the conventions of theatre and their continuing relevance in the present day and asked whether the modernist black box and its claim to give greater emphasis to the work of the performer still held true. When the black performer Jenny Larrue came onstage, the darkness foregrounded her invisibility rather than her visibility and this simple but effective stage device was used to illustrate how the black box obscures as much as it 


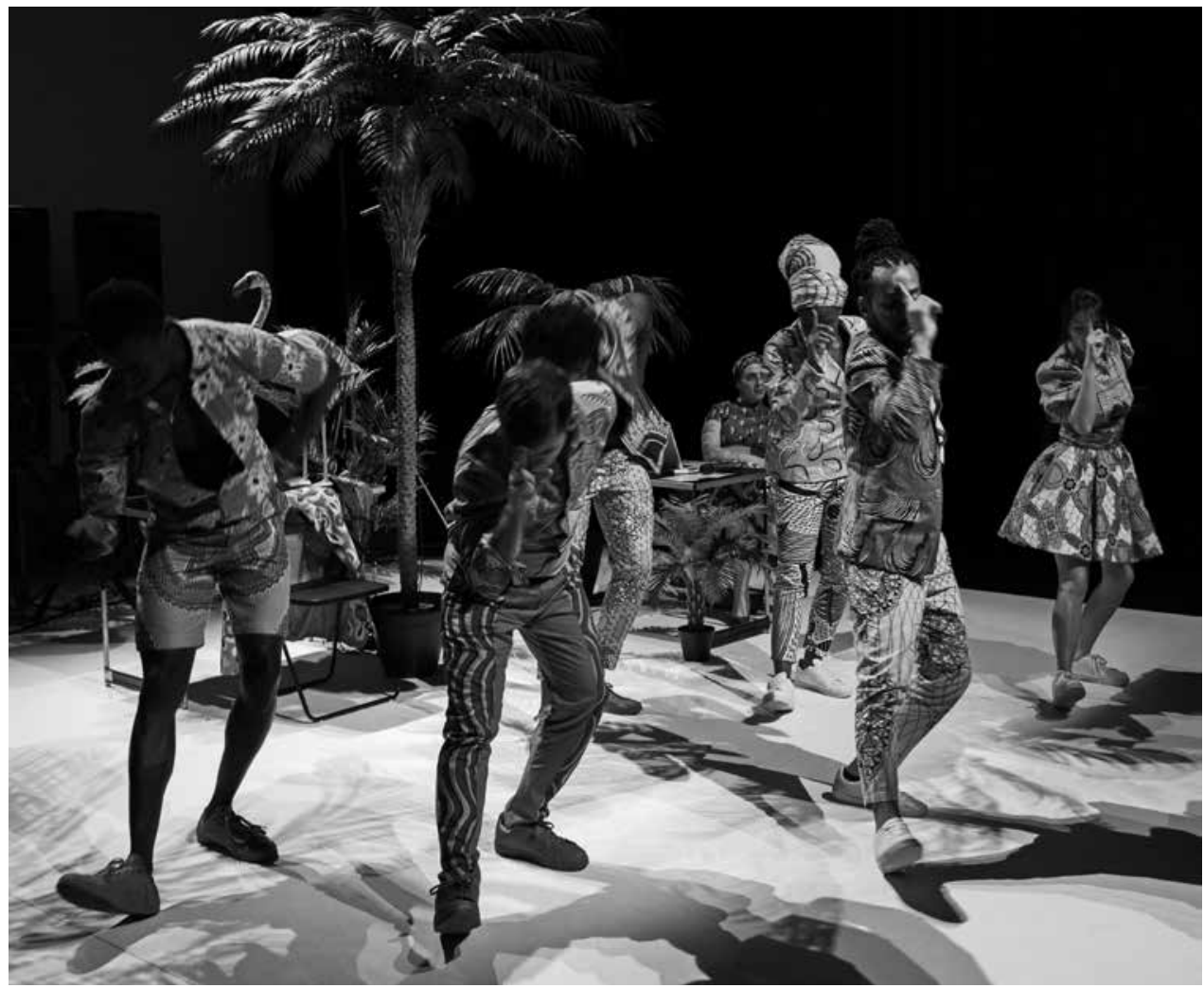

MOÇAMBIQUE, DIR. JORGE ANDRADE, MALA VOADORA, 2016 (WELKET BUNGUÉ, JORGE ANDRADE, BRUNO HUCA, MATAMBA JOAQUIM, ISABÉL ZUAA, TÂNIA ALVES [SENTADA], JANI ZHAO), [F] JOSÉ CARLOS DUARTE

makes present. Throughout the rest of the performance, several invectives were addressed to the black box and its normative pretensions and it was suggested towards the end of the performance that the days of the black box might be over. In a parodic sequence involving a well-known real estate company, they even tried to sell it off to the highest bidder. In its place, Teatro Praga placed the Pessoan idea of a "performance in people rather than acts" ${ }^{1}$ and the need for creative invention implicit in the term "Zululuzu".

The neologism "ZuluLuzu" covered a wide territory here. It ranged from Rosa Luxemburg to three-legged cats to Donna Haraway. All were summoned to reinvent the stage space and to question both notions of "Portugueseness" and "Africannness". Brazil was evoked through the conventions of romantic song, but the focus was more often on Portugal and the Portuguese presence in Africa. The performance's connection

1 "É um drama em gente, em vez de actos". Quoted in the production programme. 


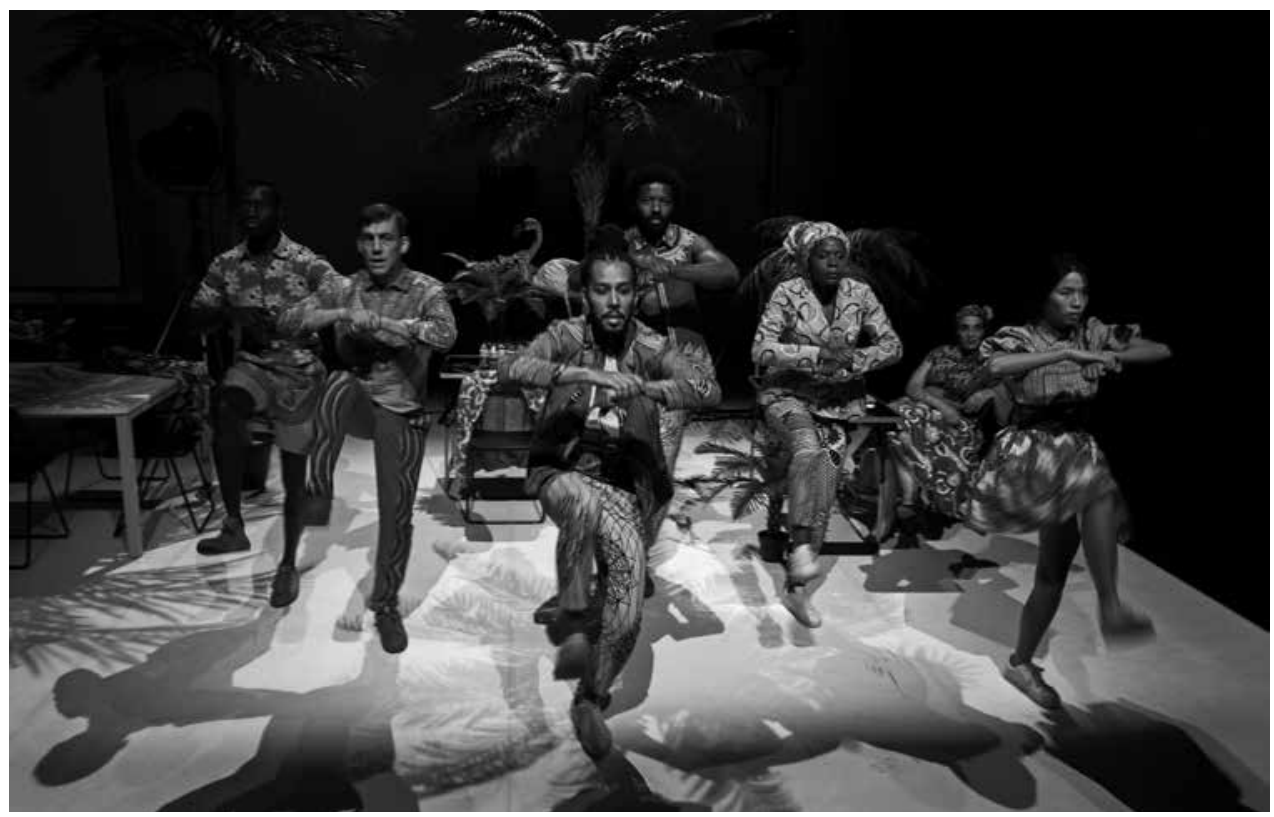

MOÇAMBIQUE, DIR. JORGE ANDRADE, MALA VOADORA, 2016 (WELKET BUNGUÉ, JORGE ANDRADE, BRUNO HUCA, MATAMBA JOAQUIM, ISABÉL ZUAA, TÂNIA ALVES [SENTADA], JANI ZHAO), [F] JOSÉ CARLOS DUARTE

with Fernando Pessoa and his short time in Durban was deliberately tenuous. In a virtuoso sequence, André e. Teodósio provided a potted biography while Jenny Larrue lip-synched an accompaniment. One of the personalities convened under the banner of Zululuzu was the Internet, but its significance as a source of information about Pessoa was dismissed and the audience was told to go and look up a poem by Pessoa themselves. What the performance did take from Pessoa was a black female heteronym, illustrating both the implicit racism of such a creation and its possibilities for contemporary resignification. Along with the stage presence of a black Fernanda, such mechanisms pointed to the history of exclusions of such figures or their exoticisation, rendering any attempt to know Africa and the African impossible. However, Teatro Praga, like mala voadora, pointed also to the limitations of identity politics in challenging such marginalization by invoking more complex intersectional identities such as black and transsexual, Portuguese and queer or Portuguese and Turkish-speaking. Indeed, queer identities were as central to this performance as black identities, both in the lavish, camp costumes worn onstage, the vogueing and dancing and the centrality of the slogan "Queer Indigenization" on a banner that was unfurled during the performance. At the end, a large white inflatable was blown up and colours were projected 


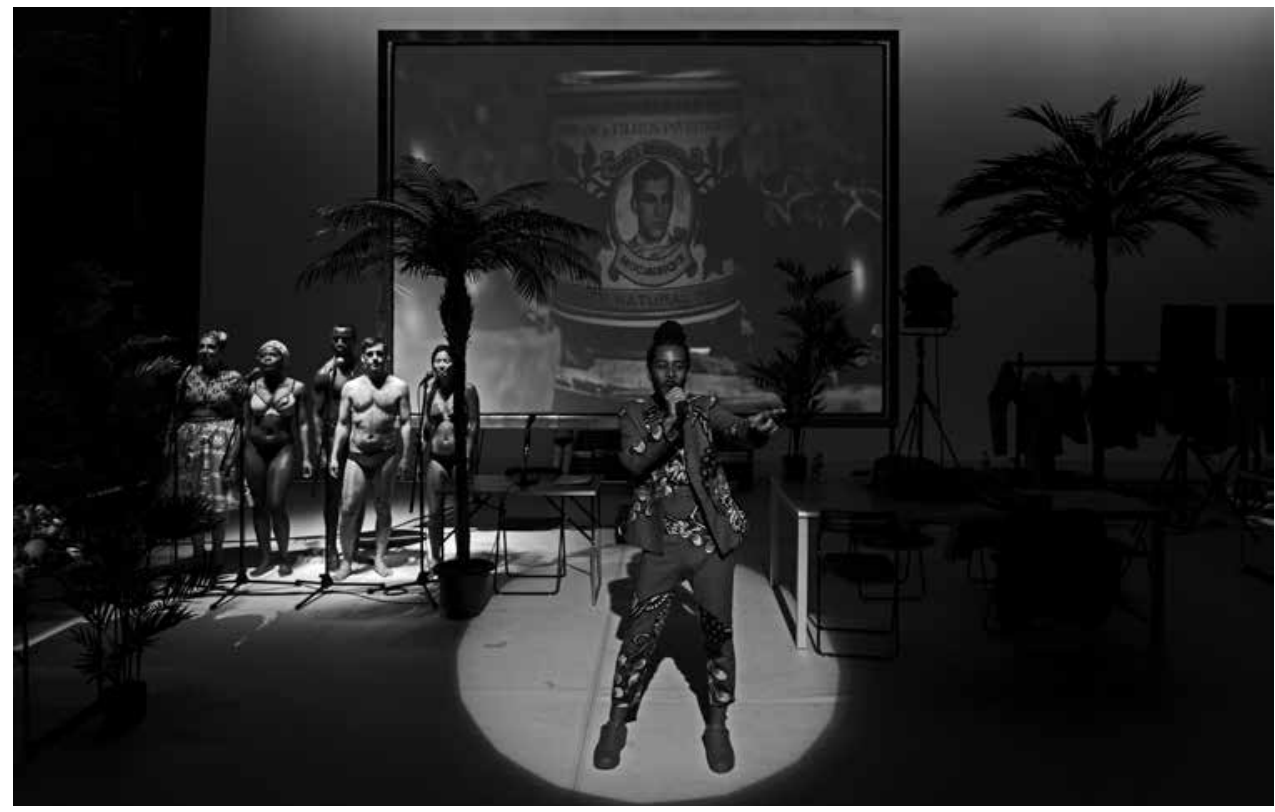

MOÇAMBIQUE, DIR. JORGE ANDRADE, MALA VOADORA, 2016 (BRUNO HUCA, TÂNIA ALVES, ISABÉL ZUAA, WELKET BUNGUÉ, JORGE ANDRADE E JANI ZHAO), [F] JOSÉ CARLOS DUARTE

onto it, referencing both the queer nation and the rainbow nation of South Africa, as well as the colour that the black box dogmatically bans from the stage. It was a fitting final image in a period of cultural and political redefinition as Europe falls apart over questions of basic human rights and the economic and political bankruptcy of Angola creates a new generation of political prisoners and a neo-liberal wave of Portuguese returnees.

The Angolan is referenced explicitly in Moçambique, as one of the black actors onstage says he is of Angolan descent, but such ethnic certainties are disrupted by the performers' own self-definitions which include a white woman who identifies herself as Indian and two performers, one black and the other Chinese, who both identify themselves as primarily Portuguese. The multicultural cast is the great strength of Moçambique and their physical energy carries the many sequences when the passing of time is suggested ingeniously by energetic collective dance routines. Such sequences were particularly effective in showing the to-and-fro movements of the peace process in Mozambique when, year after year, the process broke down and started again, with the dancers continuing to dance, increasingly exhaustedly, until peace finally came. There was also an excellent sequence where the exportation of canned tomatoes to first Western and then Eastern bloc nations gave rise to a series of perfectly-executed sung advertising slogans 
in a variety of different languages and styles, illustrating the various foreign presences in post-colonial Moçambique that tore the country apart.

The central conceit of Mozambique poked fun at the current vogue for documentary theatre and accused it of a certain modernist naivety. Linking the personal history of Jorge Andrade (or maybe not?) and the chequered history of Mozambique, Andrade began the performance with the story of a family connection with a tomato processing plant in the country and the offer made to him to take over the plant by his aunt and uncle. Nothing guaranteed that any of this was "true" or "real" and indeed later in the performance, Andrade indicated that the fallibility of memory had interfered with even his most treasured "personal" memory. The performers collectively imagined what might have happened if Andrade had in fact chosen to stay in Angola and made use of this conceit to focus on the difficulties of documenting the collective history of Mozambique and its relationship with Portugal from the perspective of the present. Black and white screen images were used to tell this story in stops and starts rather than in linear fashion, although the images of the civil war dead thrown into mass graves or simply left lying on the ground was a reminder that a focus on the fragmentation of history-making and the difficulties of using realist forms, such as film to tell such a story, did not lessen the impact of real and harrowing historical events such as these. The performance was built around the recurring national and political disasters and sordid political games that blighted the progress of Mozambique in the post-colonial period with a consistent emphasis on the ways in which such events might have been cast differently. The onstage performers worked together to create a story of what might have been, illustrating in this way the particular contribution that performance can make to the prismatic understanding of personal and collective histories. They showed how strongly-held beliefs and the desire for happy endings, for instance, or individual qualities and defects, influence the development of the stories we tell ourselves about history; as well as the centrality of imagination and creativity in negotiating a collective version of events among very different individuals with different backgrounds and desires. Such differences made the construction of historical narrative a complex but energising experience that was constantly open to being reconstructed.

As with Teatro Praga's Zululuzu, the costumes in Moçambique were a delight, working with contemporary redefinitions of the use of traditional materials and patterns. The area of costume design and confection is an area that is often the subject of post-performance discussions 
among members of the audience but rarely makes its way into critical reviews of performance. Yet in both these performances, costume played a central role in the invocation and then deconstruction of the narratives of Africa the performances created.

In both these performances "Africa" and the "Africans" were a tool for the companies to experiment with stage languages other than the textualwhether music, dance or the visual arts. In Zululuzu, there was a sequence where the performers used a flipchart to illustrate the various clichés used when talking about Africa, such as starving children, zebras or Nelson Mandela, but neither performance tackled the question of the representation of Africa directly. Instead, they used the "African" as a counterpoint to the "Portuguese", a way of denaturalizing what is taken for granted as the DNA of the Portuguese experience and of Portuguese theatre. Zululuzu was perhaps more ambitious in its scope, although sometimes repetitive and uncoordinated, while Moçambique was tighter and more coherent as a performance. Zululuzu was primarily for theatre people (I saw some confused-looking Portuguese teachers who had obviously come expecting to see something about Fernando Pessoa), while Moçambique, because of its focus on recent history and historiography, appealed to a wider audience. Both performances were a good night out - bright and colourful with lots of humour. Both performances involved extensive research which they nevertheless wore lightly. Both performances are to be welcomed for pointing to new directions for Portuguese theatre in the wake of growing European disenchantment, but in order for such performances not merely to invoke and deconstruct the ghosts of Africa and their relationship with Portugal, it is necessary to reinforce the central message of including more black actors and actresses, as well as writers and directors, on Portuguese stages. Increased visibility does not equal increased power. As Peggy Phelan (1993: 10) once commented ironically, if increased visibility did lead to increased power, "then almost-naked young white women should be running Western culture". However, as these performances suggest, a self-conscious exploration of questions of absence and presence can promote greater diversity onstage and thus encourage a wider understanding of the contemporary in contemporary theatre. 